\title{
AN INTEGRATED ASSESSMENT OF LITHUANIAN ECONOMIC SECTORS BASED ON FINANCIAL RATIOS AND FUZZY MCDM METHODS
}

\author{
Alvydas Baležentis ${ }^{1}$, Tomas Baležentis ${ }^{2}$, Algimantas Misiūnas ${ }^{3}$ \\ ${ }^{1}$ Mykolas Romeris University, Valakupiu g. 5, LT-10101 Vilnius, Lithuania \\ ${ }^{2,3}$ Vilnius University, Sauletekio al. 9, LT-10222 Vilnius, Lithuania \\ E-mails: ${ }^{1}$ a.balezentis@gmail.com; ${ }^{2}$ t.balezentis@gmail.com (corresponding author); \\ 3a.misiunas@gmail.com
}

Received 06 February 2011; accepted 13 July 2011

\begin{abstract}
The aim of this study was to offer a novel procedure for integrated assessment and comparison of Lithuanian economic sectors on the basis of financial ratios and fuzzy MCDM methods. The complex of interrelated issues regarding integrated assessment of economic sectors is discussed in the paper. The object of research is financial indicators of different Lithuanian economic sectors. The proposed procedure for multi-criteria comparison of economic sectors encompasses: 1) the indicator system, 2) application of fuzzy MCDM methods, and 3) inter-sectoral comparison based on ranks provided by fuzzy MCDM methods. The research covers period of 2007-2010, starting at the very beginning of the economic recession and, hopefully, ending with the upcoming recovery. The application of the three MCDM methods was successful. The results suggested the best performing sector being that of forestry and logging. Furthermore, enterprises operating in trade sector, hospitality sector, mining and quarrying sector, information sector, or manufacturing sector can be considered as working more efficiently than an average Lithuanian enterprise. At the other end of spectrum, construction, real estate, and transportation sectors were those severely damaged by the economic crisis: they were ranked below the average alternative. Meanwhile, relatively low positions of utilities sectors may be caused by their specifics. Finally, the transport sector can be considered as the typical victim of economic downturn.
\end{abstract}

Keywords: financial ratios, economic sectors, Lithuania, fuzzy number, VIKOR, TOPSIS, ARAS, strategic management.

Reference to this paper should be made as follows: Baležentis, A.; Baležentis, T.; Misiūnas, A. 2012. An integrated assessment of Lithuanian economic sectors based on financial ratios and fuzzy MCDM methods, Technological and Economic Development of Economy 18(1): 34-53.

JEL Classification: C44, D24, M21. 


\section{Introduction}

The economic processes can be analyzed at three levels, namely those of enterprise, economic sector, or state. The renowned international organizations have developed respective methods for inter-state comparison, focused on competitiveness, innovativeness etc. The inter-sectoral comparison, however, remains virtually underdeveloped area, for there had been only investigations on specific areas of energy efficiency or international trade. Moreover, Lithuanian economy is even less researched. Our study is hence oriented towards solving the problem of the lack of general framework for inter-sectoral comparison of efficiency. In addition, we employ Statistics Lithuania data and fuzzy multi-criteria decision making methods for aforementioned purpose for the first time. The proposed multi-criteria assessment model might provide a rationale for a variety of stakeholders-politicians, businessmen, employees, and investors-who needs to appropriately aid its decisions. To conclude, this paper introduces the application of fuzzy multi-criteria decision making methods and financial ratios in evaluation of Lithuanian economic sector efficiency.

This paper analyzes the performance of main Lithuanian economic sectors from the viewpoint of financial ratios. For certain financial ratios identify both the efficiency and competitiveness of national economic sectors. Obtained from financial statements of enterprises, these ratios can help to ascertain whether the enterprises are operating effectively, are able to meet their liabilities, etc. (Peterson Drake, Fabozzi 2010). In addition, the Statistics Lithuania disseminates the surveys of the investigated enterprises' balance sheets on a regular basis. These data provide basis for a valid research. The summarized data therefore enable to investigate these peculiarities at the inter-sectoral level or their evolution over the time at the sectoral level.

The topic of portfolio management has been discussed in many studies (Markowitz 1952, 1959; Elton et al. 2007; Zopounidis, Doumpos 2002; Xidonas et al. 2010b, 2011). Consequently, one general trend can be outlined: the mean-variance method offered by Markowitz (1952) is being superseded by more robust multi-criteria analysis which pays respect to various financial indicators and ratios. The appropriately employed analysis of financial ratios can thus result in a robust portfolio selection as well as other business or government decisions. Financial ratio analysis has been widely applied in recent studies (Ginevičius, Podvezko 2006; Ocal et al. 2007; Wang 2008; Wu et al. 2009; Wang, Lee 2010; Mackevičius, Valkauskas 2010). Indeed, these studies were aimed at comparison of different enterprises. Misiūnas (2010) analyzed the performance of Lithuanian economic sectors on the basis of financial ratios. As it was proved by previous studies (Xidonas, Psarras 2009; Xidonas et al. 2009b, 2010a), the application of multi-criteria decision making methods significantly improves the robustness of financial analysis and business decisions in general. This study hence puts forward the practice of inter-sectoral comparison based on financial ratios analysis by introducing the application of fuzzy multi-criteria decision making (MCDM) methods. Whereas single financial ratio hardly provides the required information, a set of financial ratios has been defined and applied in the analysis.

As some authors (Kahraman 2008; Norkus 2009) argued, fuzzy set theory (Zadeh 1965) plays an important role in social sciences and humanities since it can cope with ambiguities, 
uncertainties, and vagueness that cannot be handled by crisp values. Consequently, three fuzzy MCDM methods were applied in this study: VIKOR (Kaya, Kahraman 2011), TOPSIS (Zavadskas, Antucheviciene 2006; Yu, Hu 2010), and ARAS (Turskis, Zavadskas 2010). The results of such studies can successfully aid strategic management decisions, namely those made by either public or private stakeholders. Moreover, the application of fuzzy number enables to take into account the dynamics of time series of the investigated indicators in a more robust way.

The object of research is financial indicators of different Lithuanian economic sectors. The aim of this study was to offer a novel procedure for integrated assessment and comparison of Lithuanian economic sectors on the basis of financial ratios and fuzzy MCDM methods. The following tasks were therefore raised: 1) to define the indicator system as well as coefficients of significance of certain criteria, 2) to apply fuzzy MCDM methods, and 3) to perform inter-sectoral comparison based on ranks provided by the three fuzzy MCDM methods. The research covers period of 2007-2010, starting at the very beginning of the economic recession and, hopefully, ending with the upcoming recovery. The data was obtained from Statistics Lithuania database (accessible on-line (http://db1.stat.gov.lt/), see tables M4032207, M4032208, M4032209).

The paper is hence organized in the following manner. Section 2 discusses the financial ratios used for the research and thus provides with criteria and alternatives for MCDM. Section 3 describes MCDM methods in general as well as fuzzy MCDM methods applied in the research. Finally, Section 4 brings in the comparison of Lithuanian economic sectors.

\section{Measuring the efficiency of economic sectors: financial ratios}

The object of our research - the efficiency of Lithuanian sectors-is closely interrelated with, albeit not limited to, the problems of corporate performance evaluation and multi-criteria portfolio selection (management). As Xidonas et al. (2010b) pointed out with reference to Maginn et al. (2007), portfolio management is a process peculiar with the following stages: 1) identification and specification of investment objectives and constraints, 2) development of investment strategies, 3 ) detailed decision on portfolio composition, 4) initiation of portfolio decisions and implementation thereof by traders, 5) measurement and evaluation of portfolio performance, 6) monitoring of investor and market conditions, and 7) implementation of any necessary rebalancing. Moreover, the portfolio management encompasses the following three steps: planning, execution and feedback. The considered model for multi-criteria inter-sectoral comparison can hence be considered as a decision aiding tool for the planning step. Here we cannot deal with the problems of portfolio management; however, one can find comprehensive reviews on the matter in other reference works (Markowitz 1952, 1959; Elton et al. 2007; Zopounidis, Doumpos 2002; Xidonas et al. 2009c, 2010b, 2010c, 2011). Nevertheless, one general trend can be outlined: the mean-variance method offered by Markowitz (1952) is being superseded by more robust multi-criteria analysis which pays respect to various financial indicators and ratios. The appropriately employed analysis of financial ratios can thus result in a robust portfolio selection as well as other business or government decisions.

Like all the remaining management decisions and analyses, financial ratio analysis can be performed at different levels of management, namely at those of enterprise, sector, or state. 
Our study is focused on the two latter options; hence certain Lithuanian economic sectors will be intercompared on the basis of financial ratios.

Financial statements provide with much information, which can lead to the calculation of multiple financial ratios. Consequently, different scientists offer different ratios as well as their classifications. For instance, Misiūnas (2010) classified the financial ratios into 1) income security ratios, 2) financial leverage ratios; and 3) cash flow to financial leverage (i.e. coverage) ratios. Peterson Drake and Fabozzi (2010) present the following classification: 1) liquidity, 2) profitability, 3) activity, 4) financial leverage, and 5) return on investment. Hence, it is important to choose the most appropriate financial ratios identifying the situation of certain economic sector.

The indicator system was constructed on the basis of expert evaluation. Firstly, the wide list of financial ratios found in relevant studies (Ginevičius, Podvezko 2006; Ocal et al. 2007; Wang 2008; Wu et al. 2009; Wang, Lee 2010; Mackevičius, Valkauskas 2010; Peterson Drake, Fabozzi 2010; Xidonas et al. 2009a) was presented to the expert group, which consisted of businessmen, academicians, and officials. The experts identified nine indicators they considered the most appropriate for evaluating the efficiency of separate Lithuanian economic sectors, namely 1) gross profit margin, 2) profitability ratio, 3) return on assets ratio, 4) debt ratio, 5) leverage ratio, 6) current ratio, 7) receivables turnover ratio, 8) fixed assets turnover ratio, 9) equity turnover ratio. However, the correlation analysis exhibited the existing intercorrelation among these indicators. Hence, three indicators (profitability ratio, debt ratio, and fixed assets turnover ratio) were excluded from further analysis.

With respect to the expert evaluation and correlation analysis, the following financial ratios were chosen for analysis: 1) gross profit margin, 2) return on assets ratio, 3) leverage ratio, 4) current ratio, 5) receivables turnover ratio, 6) equity turnover ratio. Noteworthy, such pattern of ratios enables one to avoid the multicollinearity problem. More specifically, the gross profit margin shows gross profit per currency unit of sales (gross profit / sales). The return on assets ratio shows pre-tax profit per currency unit of assets (pre-tax profit / assets). The leverage ratio shows how many times owner's equity covers his liabilities (equity / liabilities). The current ratio measures current assets available to cover current liabilities (current assets / current liabilities). The receivables turnover ratio indicates how rapidly an enterprise receives payments for goods and services delivered (sales / amounts receivable in one year). The equity turnover ratio identifies how efficiently the owner's equity is used when generating income (sales / equity). These indicators are measured in different dimensions, namely per cent or times, hence the application of MCDM methods is actual. Main characteristics of the proposed criteria system are summarized in Table 1. As we can see, leverage ratio is the sole cost criterion, whereas the remaining criteria are benefit ones.

Currently Statistics Lithuania uses NACE 2 economic activity classification system. Consequently, twelve NACE 2 positions were chosen for further analysis, eleven of them describing certain economic sector and one describing Lithuanian enterprises (i.e. all economic sectors) in general. Therefore, there are $i=1,2, \ldots, 12$ alternatives and $j=1,2, \ldots, 6$ criteria to be considered in the MCDM analysis. Moreover, respective coefficients of significance were obtained for each of criteria. It was assumed that financial ratios peculiar with higher degree of variance and thus variation tend to be less important for some sectors. On the other 
Table 1. Financial ratios for multi-criteria evaluation of economic sectors

\begin{tabular}{lcccc}
\hline \multicolumn{1}{c}{ Financial ratios } & $\begin{array}{c}\text { Units of } \\
\text { measurement }\end{array}$ & $\begin{array}{c}\text { Direction of } \\
\text { optimization }\end{array}$ & $\begin{array}{c}\text { Possible } \\
\text { negative value }\end{array}$ & $\begin{array}{c}\text { Coefficient of } \\
\text { significance }\left(\boldsymbol{w}_{\boldsymbol{j}}\right)\end{array}$ \\
\hline 1. Gross profit margin & Per cent & $\operatorname{Max}$ & + & 0.21 \\
\hline 2. Return on assets ratio & Per cent & $\operatorname{Max}$ & + & 0.08 \\
\hline 3. Leverage ratio & Times & $\operatorname{Min}$ & - & 0.12 \\
\hline 4. Current ratio & Times & $\operatorname{Max}$ & - & 0.23 \\
\hline 5. Receivables turnover ratio & Times & $\operatorname{Max}$ & - & 0.23 \\
\hline 6. Equity turnover ratio & Times & $\operatorname{Max}$ & - & 0.13 \\
\hline
\end{tabular}

hand, those ratios with low variation can be considered as being of the uniform importance for all sectors and thus more important in general. Firstly, coefficients of variation $c_{v j}$ were computed for all $j$. Secondly, the reciprocal values were computed and added up. Thirdly, the weights were obtained:

$$
w_{j}=\frac{1 / c_{v j}}{\sum_{j=1}^{6} 1 / c_{v j}}, \forall j .
$$

The results of the analysis are rather well-grounded: return on assets ratio, leverage ratio, and equity turnover ratio appeared to have the lowest significance. Actually, different economic sectors do not need the same amount of assets to generate profit and hence the importance of the return on assets ratio might be reduced. The same can be applied for the remaining two financial ratios. Since the further analysis is based on triangular fuzzy numbers, respective fuzzy significance coefficient will be defined according to crisp values obtained by Eq. $1: \tilde{w}_{j}=\left(w_{j} ; w_{j} ; w_{j}\right), \forall j$.

\section{MCDM methods}

Multiple criteria decision making (MCDM) methods enable to choose the best alternative from either finite or infinite set of alternatives. Multiple attribute decision making (MADM) methods are applied when dealing with the former class of problems. The term MCDM will henceforth refer to MADM methods in this article. Noteworthy, MCDM methods can be applied when performing multi-dimensional analysis, as these methods evaluate the alternatives according to system of indicators rather than certain single indicator. The latter practice would lead to mono-criterion analysis which may be unsuitable for some complex issues.

Roy (1996) presented the following pattern of MCDM problems: 1) a choosing problematique - choosing the best alternative from a set of available alternatives, 2) $\beta$ sorting problematique - classifying alternatives of a set of available alternatives into relatively homogenous groups, 3) $\gamma$ ranking problematique - ranking alternatives of a set of available alternatives from best to worst, 4) $\delta$ describing problematique - describing alternatives of a set of available alternatives in terms of their peculiarities and features.

The field of MCDM has been robustly developing since 1960s. MacCrimmon (1968) described the first multi-criteria evaluation methods (e.g. SAW - Simple Additive Weighing), whereas Keeney and Raiffa (1976) advanced in field of MCDM studies by employing multi- 
ple attribute utility function in analysis. Moreover, MacCrimmon (1968) described the two stages of weighing, namely 1) voting in an executive committee for significance coefficients of each criterion, and 2) normalizing the values of criteria. Hence, the MCDM methods differ in 1) selection of significance coefficients, 2) normalization procedures, which can be either internal or external (Brauers 2007), 3) selection of the best alternative, 4) scaling the objectives, and 4) additional parameters affecting the solution (Zavadskas, Turskis 2010; Zavadskas et al. 2010c).

However, the rank correlation methods were the first to be applied in multi-criteria analysis. Rank correlation was first introduced by psychologist Spearman (1904) and later taken over by statistician Kendall (1970). ELECTRE (Roy 1968; Ulubeyli, Kazaz 2009; Xidonas et al. 2009a), NAIADE (Munda et al. 1995; Munda 1995, 2005), PROMETHEE (Brans, Mareschal 1992; Behzadian et al. 2010; Podvezko, V., Podviezko, A. 2010) are families of MCDM methods based on outranking preferences. Analytic Hierarchy Process (AHP) was proposed and developed by Saaty $(1980,1997)$. It enables to obtain significance coefficients for criterion used in multi-criteria decision making. Application of AHP is discussed by Krajnc and Glavič (2005) and Podvezko (2009). Buckley (1985) updated AHP with fuzzy number theory. A new method for estimation of significance coefficients_SWARA—-has been developed (Keršulienè et al. 2010). The Reference Point approach is applied in such methods as TOPSIS, COPRAS, VIKOR and MOORA. Technique for the Order Preference by Similarity to Ideal Solution (TOPSIS) was introduced by Hwang and Yoon (1981) and modified by applying grey numbers (Lin et al. 2008), fuzzy numbers (Wang et al. 2003) or Mahalanobis distance (Antuchevičienè et al. 2010). Practice of these two latter methods covers various studies (Zavadskas et al. 2010a; Ginevičius, Podvezko 2009). Method of Complex Proportional Assessment (COPRAS) (Zavadskas et al. 1994) was improved by applying grey number technique (Zavadskas et al. 2008a, 2008b, 2009b, 2010a) as well as fuzzy numbers (Zavadskas, Antucheviciene 2007), and used in many studies (Ginevičius, Podvezko 2009; Zavadskas et al. 2009a; Tupenaite et al. 2010). VIKOR method is based on linear normalization (Opricovic, Tzeng 2002, 2004; Antucheviciene, Zavadskas 2008). Cevikcan et al. (2009) discussed application of fuzzy VIKOR method. Multi-Objective Optimization by Ratio Analysis (MOORA) method was offered by Brauers and Zavadskas (2006) on the basis of previous researches (Brauers 2004). This method was further developed (Brauers, Zavadskas 2010) and became MULTIMOORA (MOORA plus the full multiplicative form). Numerous examples of application of these methods are present (Brauers et al. 2010; Brauers, Ginevičius 2009, 2010; Baležentis et al. 2010). Brauers et al. (2011) have also presented fuzzy MULTIMOORA. In addition, there are well known additive methods developed. Simple Additive Weighing (SAW) method (MacCrimmon 1968) was modified in these ways: simplified (Ginevičius et al. 2004; Ginevičius, Podvezko 2009) and updated with grey numbers technique (Zavadskas et al. 2010b) and extended into fuzzy environment (Chou et al. 2008). New Additive Ratio Assessment (ARAS) method was introduced by Zavadskas and Turskis (2010) and subsequently extended into fuzzy environment (Turskis, Zavadskas 2010). A more detailed overview of MCDM methods is presented by Guitouni and Martel (1998).

As it was mentioned above, the three fuzzy methods, namely VIKOR, TOPSIS, and ARAS, will be applied in the analysis. This section, therefore, continues with describing the fuzzy set theory and the fuzzy MCDM methods. 


\subsection{The fuzzy set theory and triangular fuzzy numbers}

Zadeh (1965) introduced the use of fuzzy set theory when dealing with problems involving fuzzy phenomena. Noteworthy, fuzzy sets and fuzzy logic are powerful mathematical tools for modelling uncertain systems. A fuzzy set is an extension of a crisp set. Crisp sets only allow full membership or non-membership, while fuzzy sets allow partial membership. The theoretical fundaments of fuzzy set theory are overviewed by Chen (2000).

In a universe of discourse $X$, a fuzzy subset $\tilde{A}$ of $X$ is defined with a membership function $\mu_{\tilde{A}}(x)$ which maps each element $x \in X$ to a real number in the interval $[0 ; 1]$. The function value of $\mu_{\tilde{A}}(x)$ resembles the grade of membership of $x$ in $\tilde{A}$. The higher the value of $\mu_{\tilde{A}}(x)$, the higher the degree of membership of $x$ in $\tilde{A}$ (Keufmann, Gupta 1991). Noteworthy, in this study any variable with tilde will denote a fuzzy number.

A fuzzy number $\tilde{A}$ is described as a subset of real number whose membership function $\mu_{\tilde{A}}(x)$ is a continuous mapping from the real line $\mathfrak{R}$ to a closed interval $[0 ; 1]$, which has the following characteristics: 1) $\mu_{\tilde{A}}(x)=0$, for all $\left.x \in(-\infty ; a] \cup[c ; \infty) ; 2\right) \mu_{\tilde{A}}(x)$ is strictly increasing in $[\mathrm{a} ; \mathrm{b}]$ and strictly decreasing in $[\mathrm{d} ; \mathrm{c}]$; 3) $\mu_{\tilde{A}}(x)=1$, for all $x \in[b ; d]$, where $a, b, d$, and $c$ are real numbers, and $-\infty<a \leq b \leq d \leq c<\infty$. When $b=d$ a fuzzy number $\tilde{A}$ is called a triangular fuzzy number represented by a triplet $(a, b, c)$. Triangular fuzzy numbers will therefore be used in this study to characterize the alternatives. In addition, the parameters $a, b$, and $c$ in can be considered as indicating respectively the smallest possible value, the most promising value, and the largest possible value that describe a fuzzy event (Torlak et al. 2010: 3).

Let $\tilde{A}$ and $\tilde{B}$ be two positive fuzzy numbers (Liang, Ding 2003). Hence, the main algebraic operations of any two positive fuzzy numbers $\tilde{A}=(a, b, c)$ and $\tilde{B}=(d, e, f)$ can be defined in the following way (Wu et al. 2009):

1. Addition + :

$$
\tilde{A}+\tilde{B}=(a, b, c)+(d, e, f)=(a+d, b+e, c+f) ;
$$

2. Subtraction -:

$$
\tilde{A}-\tilde{B}=(a, b, c)-(d, e, f)=(a-d, b-e, c-f) ;
$$

3. Multiplication $\times$ :

$$
\tilde{A} \times \tilde{B}=(a, b, c) \times(d, e, f)=(a \times d, b \times e, c \times f) ;
$$

4. Division $\div$ :

$$
\tilde{A} \div \tilde{B}=(a, b, c) \div(d, e, f)=(a / f, b / e, c / d) .
$$

The vertex method can be applied to measure the distance between two fuzzy numbers. Let $\tilde{A}=(a, b, c)$ and $\tilde{B}=(d, e, f)$ be two triangular fuzzy numbers. Then, the vertex method can be applied to measure the distance between these two fuzzy numbers:

$$
d(\tilde{A}, \tilde{B})=\sqrt{\frac{1}{3}\left[(a-d)^{2}+(b-e)^{2}+(c-f)^{2}\right]} .
$$

Fuzzy numbers can be applied in two ways when forming the response matrix of alternatives on objectives. First, fuzzy numbers can represent the values of linguistic variables 
when deciding either on the importance of criteria or performing qualitative evaluation of alternatives. For the latter purpose Chen (2000) describes the following fuzzy numbers identifying values of linguistic variables from scale Very poor to Very good: Very poor $(0,0,1)$; Poor - $(0,1,3)$; Medium poor - $(1,3,5)$; Fair - $(3,5,7)$; Medium good - $(5,7,9)$; Good - $(7,9,10)$; Very good - $(9,10,10)$. Second, the fuzzy numbers can represent monetary (quantitative) terms. It can be done either through direct input of certain fuzzy numbers into the response matrix or by aggregation of raw data (e.g. time series). For example, if there are costs "approximately equal to $\$ 200$ " estimated, the sum can be represented by triangular fuzzy number $(190,200,210)$. Moreover, the fuzzy numbers can embody expected rate of growth. For example, if there is level of unemployment of 5 per cent with expected growth of 10 per cent, a triangular fuzzy number $(5,5.5,6.1)$ can summarize these characteristics. As for time series data, a fuzzy number can represent the dynamics of certain indicator during past $t$ periods:

$$
\left(\min _{p}\left\{a_{p}\right\}, \frac{\sum_{p=1}^{t} a_{p}}{t}, \max _{p}\left\{a_{p}\right\}\right),
$$

where $a_{p}$ represents the value of certain indicator during period $p=1,2, \ldots, t$. Moreover, the application of two-tuple linguistic representation would enhance the heterogeneous data fusion (Liu, Zhang 2011).

The results of comparison of alternatives based on fuzzy numbers are also expressed in fuzzy numbers. The fuzzy numbers therefore need to be converted into crisp ones in order to identify the most promising alternative. There are four defuzzification methods commonly employed: (i) the centroid method (or centre of area - COA); (ii) Mean-of-maximum (MOM); (iii) $\alpha$-cut method; and (iv) signed distance method (Zhao, Govind 1991; Yao, Wu 2000).

\subsection{Fuzzy MCDM methods}

Let us assume we have the fuzzy decision making matrix $\tilde{X}=\tilde{x}_{i j}$, where $i=1,2, \ldots, m$ and $j=1,2, \ldots, n$ denote the number of alternatives and criteria respectively. In our study, we have $m=12$ and $n=6$. The $j^{\text {th }}$ criterion of the $i^{\text {th }}$ alternative is represented by triangular fuzzy number: $\tilde{x}_{i j}=\left(x_{i j 1}, x_{i j 2}, x_{i j 3}\right)$. Moreover, each $j^{\text {th }}$ criterion is assigned with respective coefficient of significance $\tilde{w}_{j}$. Benefit criteria are members of benefit criteria set $B$, whereas cost criteria are members of respective set $C$.

This subsection further describes each of the three methods applied in the analysis: fuzzy VIKOR, fuzzy TOPSIS, and fuzzy ARAS.

\subsubsection{Fuzzy VIKOR}

Fuzzy VIKOR (Chen, Wang 2009; Kaya, Kahraman 2011) was developed on a basis of crisp VIKOR introduced by Opricovic and Tzeng $(2002,2004)$. VIKOR is based on measuring the closeness to the ideal alternative according to separate cases of $L_{p}$ metric. 
First of all, the fuzzy best values $\tilde{f}_{j}^{*}$ and the fuzzy worst values $\tilde{f}_{j}^{-}$are found:

$$
\begin{aligned}
& \tilde{f}_{j}^{*}=\max _{i} \tilde{x}_{i j}, \forall j \in B ; \quad \tilde{f}_{j}^{*}=\min _{i} \tilde{x}_{i j}, \forall j \in C ; \\
& \tilde{f}_{j}^{-}=\min _{i} \tilde{x}_{i j}, \forall j \in B ; \quad \tilde{f}_{j}^{-}=\max _{i} \tilde{x}_{i j}, \forall j \in C .
\end{aligned}
$$

Subsequently, the distances of each alternative from the ideal one are determined:

$$
\begin{gathered}
\tilde{S}_{i}=\sum_{j=1}^{n} \tilde{w}_{j}\left(\tilde{f}_{j}^{*}-\tilde{x}_{i j}\right) /\left(\tilde{f}_{j}^{*}-\tilde{f}_{j}^{-}\right), \forall i ; \\
\tilde{R}_{i}=\max _{j}\left[\tilde{w}_{j}\left(\tilde{f}_{j}^{*}-\tilde{x}_{i j}\right) /\left(\tilde{f}_{j}^{*}-\tilde{f}_{j}^{-}\right)\right], \forall i .
\end{gathered}
$$

The reference point is defined by computing values of $\tilde{S}^{*}, \tilde{S}^{-}, \tilde{R}^{*}$, and $\tilde{R}^{-}$, which, in turn, enable to obtain the final summarizing ratio $\tilde{Q}_{i}$ :

$$
\begin{gathered}
\tilde{S}^{*}=\min _{i} \tilde{S}_{i} ; \quad \tilde{S}^{-}=\max _{i} \tilde{S}_{i} ; \quad \tilde{R}^{*}=\min _{i} \tilde{R}_{i} ; \quad \tilde{R}^{*}=\max _{i} \tilde{R}_{i} ; \\
\tilde{Q}_{i}=v\left(\tilde{S}_{i}-\tilde{S}^{*}\right) /\left(\tilde{S}^{-}-\tilde{S}^{*}\right)+(1-v)\left(\tilde{R}_{i}-\tilde{R}^{*}\right) /\left(\tilde{R}^{-}-\tilde{R}^{*}\right), \forall i,
\end{gathered}
$$

where $v \in[0,1]$ stands for weight of the strategy of the maximum group utility and usually is chosen such that $v=0.5$. The fuzzy number $\tilde{Q}_{i}=\left(q_{i 1}, q_{i 2}, q_{i 3}\right)$ is defuzzified by employing the following equation (Kaya, Kahraman 2011):

$$
Q_{i}=\frac{q_{i 1}+4 q_{i 2}+q_{i 3}}{6} .
$$

The best alternative, therefore, is found by minimizing value of $Q_{i}$.

\subsubsection{Fuzzy TOPSIS}

The fuzzy TOPSIS method (Yu, Hu 2010) relies on the vertex method. First of all, the aspired level and the worst level values obtained by Eq. 8 are used when normalizing the data:

$$
\tilde{r}_{i j}=\frac{\left|\tilde{x}_{i j}-\tilde{f}_{j}^{-}\right|}{\left|\tilde{f}_{j}^{*}-\tilde{f}_{j}^{-}\right|}, \forall j, i,
$$

with $\tilde{r}_{i j}$ being the normalized value of the $j^{\text {th }}$ criterion of the $i^{\text {th }}$ alternative. The normalized matrix is therefore weighed by multiplying each $\tilde{r}_{i j}$ from respective fuzzy coefficient of significance:

$$
\tilde{v}_{i j}=\tilde{w}_{j} \times \tilde{r}_{i j}, \forall j, i \text {. }
$$

The positive ideal solution $A^{+}$as well as the negative ideal solution $A^{-}$are found:

where

$$
\begin{aligned}
& A^{+}=\left(\tilde{v}_{1}^{+}, \tilde{v}_{2}^{+}, \ldots, \tilde{v}_{n}^{+}\right) ; \\
& A^{-}=\left(\tilde{v}_{1}^{-}, \tilde{v}_{2}^{-}, \ldots, \tilde{v}_{n}^{-}\right),
\end{aligned}
$$

$$
\tilde{v}_{j}^{+}=\max _{i} \tilde{v}_{i j}, \forall j ; \quad \tilde{v}_{j}^{-}=\min _{i} \tilde{v}_{i j}, \forall j .
$$

Afterwards, distances of each alternative from the ideal solutions are measured by employing Eq. 6: 


$$
d_{i}^{+}=\sum_{j=1}^{n} d\left(\tilde{v}_{i j}, \tilde{v}_{j}^{+}\right), \forall i ; \quad d_{i}^{-}=\sum_{j=1}^{n} d\left(\tilde{v}_{i j}, \tilde{v}_{j}^{-}\right), \forall i,
$$

with $d_{i}^{+}$and $d_{i}^{-}$being the distance from the positive and negative ideal solutions respectively. Finally, the relative proximity to the positive ideal solution is computed as follows:

$$
C C_{i}=\frac{d_{i}^{-}}{d_{i}^{-}+d_{i}^{+}}, \forall i .
$$

The best alternative, hence, is found by maximizing the value of closeness coefficient $C C_{i}$.

\subsubsection{Fuzzy ARAS}

The fuzzy ARAS (Turskis, Zavadskas 2010) is based on comparing every alternative with the hypothetic ideal one. With $\tilde{x}_{i j}=\left(x_{i j 1}, x_{i j 2}, x_{i j 3}\right)$, the ideal alternative is described in the following way:

$$
\tilde{x}_{0 j}=\max _{i} x_{i j 3}, \forall j \in B \quad \tilde{x}_{0 j}=\min _{i} x_{i j 1}, \forall j \in C .
$$

Subsequently, the normalized values $\tilde{\bar{x}}_{i j}$ are obtained:

$$
\begin{gathered}
\tilde{\bar{x}}_{i j}=\frac{\tilde{x}_{i j}}{\sum_{i=0}^{m} \tilde{x}_{i j}}, \forall j \in B ; \\
\tilde{\bar{x}}_{i j}=\frac{\tilde{1}^{1} / \tilde{x}_{i j}}{\sum_{i=0}^{m} \tilde{1} / \tilde{x}_{i j}}, \forall j \in C .
\end{gathered}
$$

Each $\tilde{\bar{x}}_{i j}$ is weighted by computing elements of the weighted-normalized matrix:

$$
\tilde{\hat{x}}_{i j}=\tilde{\bar{x}}_{i j} \times \tilde{w}_{j}, \forall j, i,
$$

where $\tilde{w}_{j}$ is coefficient of significance and $\tilde{\hat{x}}_{i j}$ is the weighted-normalized value of the $j^{\text {th }}$ criterion of the $i^{\text {th }}$ alternative. The overall utility $\tilde{S}_{i}$ of the $i^{\text {th }}$ alternative is computed in the following way:

$$
\tilde{S}_{i}=\sum_{j=1}^{n} \tilde{\hat{x}}_{i j}, i=0,1, \ldots, m .
$$

Since $\tilde{S}_{i}=\left(s_{i 1}, s_{i 2}, s_{i 3}\right)$ is a fuzzy number, the COA method is applied for defuzzification:

$$
S_{i}=\frac{s_{i 1}+s_{i 2}+s_{i 3}}{3}, i=0,1, \ldots, m .
$$

Finally, the relative utility of the $i^{\text {th }}$ alternative $K_{i}$ is found:

$$
K_{i}=S_{i} / S_{0}, i=0,1, \ldots, m,
$$

where $K_{i} \in[0,1]$. The best alternative is found by maximizing value of $K_{i}$.

\section{Comparing the efficiency of Lithuanian economic sectors}

This section presents the comparison of the selected economic sectors based on financial ratios described in Section 2 and application of MCDM methods discussed in Section 3. 
As Table 1 suggests, gross profit margin and return on assets can be expressed in negative numbers. These indicators can be transformed by adding modulus of the lowest negative value of certain indicator to all values of that indicator. After summarizing the initial data (Annex A, Table 3), we realized that the problem occurred for the latter ratio only (the lowest value of -5.4 per cent was observed). Hence, all the values of that indicators for all economic activities were transformed by adding 5.4 percentage points $(0.054)$ to their initial values.

The transformed initial data were summarized into the fuzzy decision matrix (Annex B, Table 4) by employing Eq. 7. Henceforth, the three fuzzy MCDM methods were applied. Fuzzy VIKOR began with Eq. 8 applied for finding respective minima and maxima. The proximity to the ideal solution was measured as defined by Eq. 9 and Eq. 10. The reference point was found by applying Eq. 11. Finally, summarizing ratios were obtained according to Eq. 12 and subsequently defuzzified by employing Eq. 13 (Table 2). Fuzzy TOPSIS method was applied by normalizing and weighting the data according to Eq. 14 and Eq. 15 respectively. The ideal solutions were determined by applying Eq. 16 and Eq. 17. The distances from those solutions were computed according to Eq. 18 and summarized by employing Eq. 19 . Table 2 presents the summarized data. As we can see, the application of the three MCDM methods was successful: the ranks of certain alternatives (i.e. economic sectors) are highly correlated. These ranks enable us to evaluate relative position of certain economic sector amidst the remaining sectors.

As Table 2 suggests, the best performing sector was that of forestry and logging. That may be caused by relatively high values of gross profit margin, current ratio, and receivables turnover ratio. These ratios indicate smooth settlements of receivables and thus generation of sufficient flow of income. Indeed, enterprise operating in trade sector, hospitality sector, mining and quarrying sector, information sector, or manufacturing sector can be considered

Table 2. Comparison of Lithuanian economic sectors efficiency according to different MCDM methods, 2007-2010

\begin{tabular}{|c|c|c|c|c|c|c|c|}
\hline \multirow{2}{*}{ Economic sectors } & \multicolumn{2}{|c|}{$\begin{array}{c}\text { Fuzzy } \\
\text { VIKOR }\end{array}$} & \multicolumn{2}{|c|}{$\begin{array}{c}\text { Fuzzy } \\
\text { TOPSIS }\end{array}$} & \multicolumn{2}{|c|}{$\begin{array}{l}\text { Fuzzy } \\
\text { ARAS }\end{array}$} & \multirow{2}{*}{$\begin{array}{l}\text { Final } \\
\text { ranks }\end{array}$} \\
\hline & $Q_{i}$ & Rank & $C C_{i}$ & Rank & $K_{i}$ & Rank & \\
\hline A02 Forestry and logging & 0.000 & 1 & 0.741 & 1 & 0.643 & 1 & 1 \\
\hline G Wholesale and retail trade; repair of vehicles & 0.576 & 4 & 0.487 & 2 & 0.510 & 2 & 2 \\
\hline I Accommodation and food service activities & 0.734 & 8 & 0.476 & 3 & 0.496 & 3 & 3 \\
\hline B Mining and quarrying & 0.485 & 2 & 0.464 & 4 & 0.409 & 4 & 4 \\
\hline J Information and communication & 0.491 & 3 & 0.458 & 5 & 0.402 & 5 & 5 \\
\hline C Manufacturing & 0.667 & 5 & 0.384 & 6 & 0.384 & 6 & 6 \\
\hline Total (all enterprises) & 0.682 & 6 & 0.341 & 7 & 0.341 & 8 & 7 \\
\hline F Construction & 0.734 & 7 & 0.327 & 8 & 0.373 & 7 & 8 \\
\hline L Real estate activities & 0.898 & 12 & 0.323 & 9 & 0.325 & 9 & 9 \\
\hline $\mathbf{H}$ Transportation and storage & 0.768 & 9 & 0.306 & 10 & 0.310 & 10 & 10 \\
\hline D Electricity, gas, steam and air conditioning supply & 0.895 & 11 & 0.222 & 11 & 0.248 & 11 & 11 \\
\hline E Water supply; sewerage, etc. & 0.840 & 10 & 0.213 & 12 & 0.247 & 12 & 12 \\
\hline
\end{tabular}


as working more efficiently than average Lithuanian enterprise. For all these sectors possess higher ranks than alternative summarizing financial ratios of all Lithuanian enterprises, namely row total with rank of 6 . Indeed, one of the best performing sectors, namely the hospitality sector, required exemptions from value added tax. However, analysis of financial ratio suggests such an exemption being unnecessary for this particular sector.

Construction, real estate, and transportation sectors were those severely damaged by the economic crisis: they were ranked below the average alternative. More specifically, construction sector was peculiar with relatively low values of gross profit margin during 2007-2010. Furthermore, both construction and real estate sectors experienced rather low values receivables turnover ratio suggesting delay in settlements peculiar for these sectors. It may be caused by common economic difficulties and shrunk aggregate demand. Relatively low positions of utilities sectors may be caused by their specifics. For instance, due to extensive and sometimes overvalued facilities networks, these sectors are peculiar with relatively high volumes of equity, which, in turn, causes relatively low equity turnover ratios. On the other hand, investments raised from borrowed funds lead to substantial level of the leverage ratio. Finally, the transport sector can be considered as the typical victim of economic downturn. For decreased sales lead to decreasing profits, and even loses in 2009.

Concluding all the above, the study proved that financial ratios can be successfully used in inter-sectoral comparisons. Survey data confirm the validity of the research. More specifically, Statistics Lithuania summarizes opinions of methodically chosen respondents active in certain economic sector. As of May 2011, the following confidence indicators were presented (Statistics Lithuania 2011): manufacturing - 1 per cent; trade - 10 per cent; construction -14 per cent; services - 28 per cent. Here, the higher values of indicator mean more positive prospective expected by businessmen in certain sector. Indeed, these findings generally coincide with results provided by our model. However, currently it is impossible to perform further validation of the obtained results, for the required data covering years 2010 and 2011 are not yet available. The further studies, hence, should be aimed at the verification. The inter-sectoral comparisons, in turn, can be performed on a basis of fuzzy MCDM methods. As a result effective strategic management decisions can be made by stakeholders at various management levels.

\section{Conclusions}

Appropriate financial ratios identify both the efficiency and competitiveness of national economic sectors. Obtained from financial statements of enterprises, these ratios can help to ascertain whether the enterprises are operating effectively, are able to meet their liabilities, etc. The summarized data, therefore, enabled to investigate these peculiarities at the inter-sectoral level or their evolution over the time at the sectoral level.

In accordance with expert evaluation and correlation analysis, the following financial ratios were chosen for analysis: 1) gross profit margin, 2) return on assets ratio, 3) leverage ratio, 4) current ratio, 5) receivables turnover ratio, 6) equity turnover ratio.

Fuzzy methods can cope with ambiguities, uncertainties, and vagueness that cannot be handled by crisp values. Hence three methods were applied in the analysis: fuzzy VIKOR, fuzzy TOPSIS, and fuzzy ARAS. Indeed, the application of the three MCDM methods was 
successful: the ranks of certain alternatives (i.e. economic sectors) were highly correlated. The following advantages can be, therefore, attributed to the proposed framework:

- The applied MCDM methods enabled to simultaneously consider multiple objectives identified by respective indicators (financial ratios). Indeed, a single financial ratio is not sufficient for robust analysis and decision aiding.

- The employed fuzzy MCDM methods enable to tackle uncertainties and vagueness peculiar for corporate performance analysis.

- The time series analysis can be carried out due to application of the fuzzy MCDM methods. Hence, triangular fuzzy numbers resembled not only a cross-section data at a certain period of time, but the generalized trend of the investigated indicators throughout the investigation period.

- Given certain sectors are peculiar with specific values of financial ratios, the coefficients of significance were given to each indicator according to its variation among sectors. However, further studies might be aimed at applying more sophisticated tools for estimation of weights, for instance, those based on linear programming.

- The introduction of a dummy alternative (total economy) virtually enables to define two groups of sectors, namely that encompassing relative efficient sectors, and another encompassing relatively inefficient ones.

The proposed framework for integrated efficiency assessment of economic sectors is, however, a generalized and tentative one. The further analysis, therefore, remains important. Such analysis could be based on data envelopment analysis or index decomposition analysis, both of which enable to identify the underlying factors (i.e. specific indicators) influencing efficiency of certain sector. The MCDM methods generally cannot handle this issue. Furthermore, the application of outranking-based MCDM methods, e.g. families of PROMETHEE and ELECTRE, NAIADE etc., would enable to avoid reasonless comparisons of alternatives. Additionally, one should be aware of trend breaks in the analyzed time series, for they can result in biased ranking.

The results suggested the best performing sector being that of forestry and logging. Furthermore, enterprises operating in trade sector, hospitality sector, mining and quarrying sector, information sector, or manufacturing sector can be considered as working more efficiently than average Lithuanian enterprise.

Construction, real estate, and transportation sectors were those severely damaged by the economic crisis: they were ranked below the average alternative. Relatively low positions of utilities sectors may be caused by their specifics. Finally, the transport sector can be considered as the typical victim of economic downturn. For decreased sales lead to decreasing profits, and even loses in 2009.

The proposed multi-criteria assessment framework can provide a rationale for interested stakeholders: government institutions and politicians; investors, financial institutions, and businessmen; employees and trade unions; clients and suppliers related with certain sectors. More specifically, the government can impose some additional fiscal measures for the best performing sectors, namely those of forestry and logging; wholesale and retail trade; repair of vehicles; hospitality etc. The investors, in turn, should opt for long-term investments in relatively inefficient sectors, i.e. construction and real estate sectors, transportation, facilities sectors. The short-term investments should be directed in the relatively efficient sectors. As 
for employees and their trade unions, they could successfully insist on increase in remuneration as well as other benefits only if their sector is an efficient one. Otherwise, these actions may lead to unsustainable decisions. Finally, clients and suppliers dealing with inefficient sectors should consider additional means for reducing risk of insolvency; for instance, credit insurance. Thus, a proper assessment of sector activity can improve the decisions of all the interested stakeholders and somehow mitigate their risks.

The study hence proved that financial ratios can be successfully used in inter-sectoral comparisons based on fuzzy MCDM methods. Consequently, effective strategic management decisions can be made at various management levels.

\section{References}

Antucheviciene, J.; Zavadskas, E. K. 2008. Modelling multidimensional redevelopment of derelict buildings, International Journal of Environment and Pollution 35(2/3/4): 331-344.

Antuchevičienè, J.; Zavadskas, E. K.; Zakarevičius, A. 2010. Multiple criteria construction management decisions considering relations between criteria, Technological and Economic Development of Economy 16(1): 109-125. http://dx.doi.org/10.3846/tede.2010.07

Baležentis, A.; Baležentis, T.; Valkauskas, R. 2010. Evaluating situation of Lithuania in the European Union: structural indicators and MULTIMOORA method, Technological and Economic Development of Economy 16(4): 578-602. http://dx.doi.org/10.3846/tede.2010.36

Behzadian, M.; Kazemzadeh, R. B.; Albadvi, A.; Aghdasi, M. 2010. PROMETHEE: a comprehensive literature review on methodologies and applications, European Journal of Operational Research 200(1): 198-215. http://dx.doi.org/10.1016/j.ejor.2009.01.021

Brans, J. P.; Mareschal, B. 1992. PROMETHEE V - MCDM problems with segmentation constraints, INFOR 30(2): 85-96.

Brauers, W. K. 2004. Optimization Methods for a Stakeholder Society, a Revolution in Economic Thinking by Multi-Objective Optimization. Boston: Kluwer Academic Publishers. http://dx.doi.org/10.1504/IJMDM.2007.013411

Brauers, W. K. 2007. What is meant by normalization in decision making?, International Journal of Management and Decision Making 8(5/6): 445-460. http://dx.doi.org/10.3846/20294913.2011.580566

Brauers, W. K. M.; Baležentis, A.; Baležentis, T. 2011. MULTIMOORA for the EU Member States updated with fuzzy number theory, Technological and Economic Development of Economy 17(2): 259-290. http://dx.doi.org/10.3846/20294913.2011.580566

Brauers, W. K. M.; Ginevičius, R. 2009. Robustness in regional development studies. The case of Lithuania, Journal of Business Economics and Management 10(2): 121-140. http://dx.doi.org/10.3846/jbem.2010.09

Brauers, W. K. M.; Ginevičius, R. 2010. The economy of the Belgian regions tested with MULTIMOORA, Journal of Business Economics and Management 11(2): 173-209. http://dx.doi.org/10.3846/tede.2010.38

Brauers, W. K. M.; Ginevičius, R.; Podvezko, V. 2010. Regional development in Lithuania considering multiple objectives by the MOORA method, Technological and Economic Development of Economy 16(4): 613-640. http://dx.doi.org/10.3846/tede.2010.38

Brauers, W. K. M.; Zavadskas, E. K. 2006. The MOORA method and its application to privatization in a transition economy, Control and Cybernetics 35(2): 445-469.

Brauers, W. K. M.; Zavadskas, E. K. 2010. Project management by MULTIMOORA as an instrument for transition economies, Technological and Economic Development of Economy 16(1): 5-24.

http://dx.doi.org/10.3846/tede.2010.01

Buckley, J. J. 1985. Fuzzy hierarchical analysis, Fuzzy Sets and Systems 17(3): 233-247. http://dx.doi.org/10.1016/0165-0114(85)90090-9 
Cevikcan, C.; Sebi, S.; Kaya, I. 2009. Fuzzy VIKOR and fuzzy axiomatic design versus to fuzzy TOPSIS: an application of candidate assessment, Journal of Multiple Valued Logic and Soft Computing 15: 181-208.

Chen, C. T. 2000. Extensions of the TOPSIS for group decision-making under fuzzy environment, Fuzzy Sets and Systems 114: 1-9. http://dx.doi.org/10.1016/S0165-0114(97)00377-1

Chen, L. Y.; Wang, T. C. 2009. Optimizing partners' choice in IS/IT outsourcing projects: the strategic decision of fuzzy VIKOR, International Journal of Production Economics 120(1): 233-242. http://dx.doi.org/10.1016/j.ijpe.2008.07.022

Chou, S. Y.; Chang, Y. H.; Shen, C. Y. 2008. A fuzzy simple additive weighting system under group decision-making for facility location selection with objective/subjective attributes, European Journal of Operational Research 189(1): 132-145. http://dx.doi.org/10.1016/j.ejor.2007.05.006

Elton, E. J.; Gruber, M. J.; Brown, S. J.; Goetzmann, W. N. 2007. Modern Portfolio Theory and Investment Analysis. 7th ed. New York: Wiley.

Ginevičius, R.; Podvezko, V. 2006. Assessing the financial state of construction enterprises, Technological and Economic Development of Economy 12(3): 188-194.

Ginevičius, R.; Podvezko, V.; Mikelis, D. 2004. Quantitative evaluation of economic and social development of Lithuanian regions, Ekonomika (65): 1-15.

Ginevičius, R.; Podvezko, V. 2009. Evaluating the changes in economic and social development of Lithuanian counties by multiple criteria methods, Technological and Economic Development of Economy 15(3): 418-436. http://dx.doi.org/10.3846/1392-8619.2009.15.418-436

Guitouni, A.; Martel, J. M. 1998. Tentative guidelines to help choosing an appropriate MCDA method, European Journal of Operational Research 109: 501-521. http://dx.doi.org/10.1016/S0377-2217(98)00073-3

Hwang, C. L.; Yoon, K. 1981. Multiple Attribute Decision Making Methods and Applications. Berlin: Springer-Verlag.

Kahraman, C. 2008. Multi-criteria decision making methods and fuzzy sets, in Kahraman, C. (Ed.). Fuzzy Multi-Criteria Decision Making. Springer. http://dx.doi.org/10.1007/978-0-387-76813-7_1

Kaya, T.; Kahraman, C. 2011. Fuzzy multiple criteria forestry decision making based on an integrated VIKOR and AHP approach, Expert Systems with Applications 38: 7326-7333. http://dx.doi.org/10.1016/j.eswa.2010.12.003

Keeney, R. L.; Raiffa, H. 1976. Decision with Multiple Objectives: Preferences and Value Tradeoffs. New York: John Wiley \& Sons.

Kendall, M. G. 1970. Rank Correlation Methods. 4th ed. London: Griffin.

Keršulienè, V.; Zavadskas, E. K.; Turskis, Z. 2010. Selection of rational dispute resolution method by applying new step-wise weight assessment ratio analysis (SWARA), Journal of Business Economics and Management 11(2): 243-258. http://dx.doi.org/10.3846/jbem.2010.12

Keufmann, A.; Gupta, M. M. 1991. Introduction to Fuzzy Arithmetic: Theory and Application. New York: Van Nostrand Reinhold.

Krajnc, D.; Glavič, P. 2005. A model for integrated assessment of sustainable development, Resources, Conservation and Recycling 43: 189-208.

Liang, G. S.; Ding, J. F. 2003. Fuzzy MCDM based on the concept of a-cut, Journal of Multi-Criteria Decision Analysis 12(6): 299-310. http://dx.doi.org/10.1002/mcda.366

Lin, Y. H.; Lee, P. C.; Chang, T. P.; Ting, H. I. 2008. Multi-attribute group decision making model under the condition of uncertain information, Automation in Construction 17(6): 792-797. http://dx.doi.org/10.1016/j.autcon.2008.02.011

Liu, P. D.; Zhang, X. 2011. Investigation into evaluation of agriculture informatization level based on two-tuple, Technological and Economic Development of Economy 17(1): 74-86. http://dx.doi.org/10.3846/13928619.2011.554007

MacCrimmon, K. R. 1968. Decision Making Among Multiple Attribute Alternatives: a Survey and Consolidated Approach. RAND Memorandum, RM-4823-ARPA. The RAND Corporation, Santa Monica, Calif. 
Mackevičius, J.; Valkauskas, R. 2010. Integruota įmonès finansinès būklès ir veiklos rezultatų analizès metodika, Verslas: teorija ir praktika [Business: Theory and Practice] 11(3): 213-221.

Maginn, J. L.; Tuttle, D. L.; Pinto, D. E.; McLeavey, D. W. 2007. Managing Investment Portfolios. 3rd ed. New York: Wiley.

Markowitz, H. 1952. Portfolio selection, The Journal of Finance 7(1): 77-91. http://dx.doi.org/10.2307/2975974

Markowitz, H. 1959. Portfolio Selection: Efficient Diversification of Investments. New York: Wiley.

Misiūnas, A. 2010. Financial ratios of the country's enterprises in the face of economic growth and decline, Ekonomika 89(1): 32-48.

Munda, G. 1995. Multicriteria Evaluation in a Fuzzy Environment. Contributions to Economics Series. Heidelberg: Physica-Verlag. http://dx.doi.org/10.1007/s10668-003-4713-0

Munda, G. 2005. Measuring Sustainability: A Multi-Criterion Framework, Environment, Development and Sustainability 7(1): 117-134. http://dx.doi.org/10.1016/0377-2217(93)E0250-2

Munda, G.; Nijkamp, P.; Rietveld, P. 1995. Qualitative multicriteria methods for fuzzy evaluation problems: an illustration of economic-ecological evaluation, European Journal of Operational Research 82(1): 79-97.

Norkus, Z. 2009. Apie klasikinę ir neklasikinę sąvokų darybą socialiniuose ir kultūros moksluose: minimalūs ir maksimalūs apibrèžimai, šeiminiai panašumai ir neraiškiosios aibès, Problemos [Problems] 75: 94-111.

Ocal, M. E.; Oral, E. L.; Erdis, E.; Vural, G. 2007. Industry financial ratios - application of factor analysis in Turkish construction industry, Building and Environment 42: 385-392. http://dx.doi.org/10.1016/j.buildenv.2005.07.023

Opricovic, S.; Tzeng, G. H. 2002. Multicriteria planning of post-earthquake sustainable reconstruction, Computer-Aided Civil and Infrastructure Engineering 17(3): 211-220. http://dx.doi.org/10.1111/1467-8667.00269

Opricovic, S.; Tzeng, G. H. 2004. Compromise solution by MCDM methods: a comparative analysis of VIKOR and TOPSIS, European Journal of Operational Research 156(2): 445-455. http://dx.doi.org/10.1016/S0377-2217(03)00020-1

Peterson Drake, P.; Fabozzi, F. J. 2010. The Basics of Finance: An Introduction to Financial Markets, Business Finance, and Portfolio Management. New Jersey: John Wiley \& Sons. http://dx.doi.org/10.1002/9781118267790

Podvezko, V. 2009. Application of AHP Technique, Journal of Business Economics and Management 10(2): 181-189. http://dx.doi.org/10.3846/1611-1699.2009.10.181-189

Podvezko, V.; Podviezko, A. 2010. Dependence of multi-criteria evaluation result on choice of preference functions and their parameters, Technological and Economic Development of Economy 16(1): 143-158. http://dx.doi.org/10.3846/tede.2010.09

Roy, B. 1996. Multicriteria Methodology for Decision Aiding. Dordrecht: Kluwer.

Roy, B. 1968. Classement et choix en présence de points de vue multiples (la méthode ELECTRE), La Revue d'Informatique et de Recherche Opérationelle (RIRO) 8: 57-75.

Saaty, T. L. 1980. Analytical Hierarchy Process: Planning, Priority Setting, Resource Allocation. New York: McGraw-Hill. http://dx.doi.org/10.1016/0022-2496(77)90033-5

Saaty, T. L. 1997. A scaling method for priorities in hierarchical structures, Journal of Mathematical Psychology 15(3): 234-281.

Spearman, C. 1904. The proof and measurement of association between two things, The American Journal of Psychology 15(1): 72-101. http://dx.doi.org/10.2307/1412159

Statistics Lithuania. 2011. Indicator database. Available from Internet: http://db1.stat.gov.lt/

Torlak, G.; Sevkli, M.; Sanal, M.; Zaim, S. 2010. Analyzing business competition by using fuzzy TOPSIS method: an example of Turkish domestic airline industry, Expert Systems with Applications 38(4): 3396-9406. http://dx.doi.org/10.1016/j.eswa.2010.08.125 
Tupenaite, L.; Zavadskas, E. K.; Kaklauskas, A.; Turskis, Z.; Seniut, M. 2010. Multiple criteria assessment of alternatives for built and human environment renovation, Journal of Civil Engineering and Management 16(2): 257-266. http://dx.doi.org/10.3846/jcem.2010.30

Turskis, Z.; Zavadskas, E. K. 2010. A new fuzzy additive ratio assessment method (ARAS-F). Case study: the analysis of fuzzy multiple criteria in order to select the Logistic Center location, Transport 25(4): 423-432. http://dx.doi.org/10.3846/transport.2010.52

Ulubeyli, S.; Kazaz, A. 2009. A multiple criteria decision-making approach to the selection of concrete pumps, Journal of Civil Engineering and Management 15(4): 369-376. http://dx.doi.org/10.3846/1392-3730.2009.15.369-376

Wang, Y. J. 2008. Applying FMCDM to evaluate financial performance of domestic airlines in Taiwan, Expert Systems with Applications 34: 1837-1845. http://dx.doi.org/10.1016/j.eswa.2007.02.029

Wang, Y. J.; Lee, H. S. 2010. Evaluating financial performance of Taiwan container shipping companies by strength and weakness indices, International Journal of Computer Mathematics 87(1): 38-52. http://dx.doi.org/10.1080/00405000701489412

Wang, Y. J.; Lee, H. S.; Lin, K. 2003. Fuzzy TOPSIS for multi-criteria decision-making, International Mathematical Journal 3: 367-379.

Wu, H. Y.; Tzeng, G. H.; Chen, Y. H. 2009. A fuzzy MCDM approach for evaluating banking performance based on balanced scorecard, Expert Systems with Applications 36: 10135-10147. http://dx.doi.org/10.1016/j.eswa.2009.01.005

Xidonas, P.; Askounis, D.; Psarras, J. 2009c. Common stock portfolio selection: a multiple criteria decision making methodology and an application on the Athens Stock Exchange, Operational Research 9(1): 55-79. http://dx.doi.org/10.1016/j.eswa.2009.03.066

Xidonas, P.; Ergazakis, E.; Ergazakis, K.; Metaxiotis, K.; Askounis, D.; Mavrotas, G.; Psarras, J. 2009b. On the selection of equity securities: an expert systems methodology and an application on the Athens Stock Exchange, Expert Systems with Applications 36(9): 11966-11980. http://dx.doi.org/10.1016/j.eswa.2009.03.066

Xidonas, P.; Mavrotas, G.; Psarras, J. 2009a. A multicriteria methodology for equity selection using financial analysis, Computers and Operations Research 36(12): 3187-3203. http://dx.doi.org/10.1016/j.cor.2009.02.009

Xidonas, P.; Mavrotas, G.; Psarras, J. 2010a. A multiple criteria decision making approach for the selection of stocks, Journal of the Operational Research Society 61: 1273-1287.

Xidonas, P.; Mavrotas, G.; Psarras, J. 2010b. Equity portfolio construction and selection using multiobjective mathematical programming, Journal of Global Optimization 47(2): 185-209. http://dx.doi.org/10.1007/s10898-009-9465-4

Xidonas, P.; Mavrotas, G.; Psarras, J. 2010c. Portfolio construction on the Athens Stock Exchange: a multiobjective optimization approach, Optimization 59(8): 1211-1229. http://dx.doi.org/10.1080/02331930903085375

Xidonas, P.; Mavrotas, G.; Zopounidis, C.; Psarras, J. 2011. IPSSIS: An integrated multicriteria decision support system for equity portfolio construction and selection, European Journal of Operational Research 210(2): 398-409. http://dx.doi.org/10.1016/j.ejor.2010.08.028

Xidonas, P.; Psarras, J. 2009. Equity portfolio management within the MCDM frame: a literature review, International Journal of Banking, Accounting and Finance 1(3): 285-309.

Yao, J. S.; Wu, K. 2000. Ranking fuzzy numbers based on decomposition principle and signed distance, Fuzzy Sets and Systems 116: 275-288. http://dx.doi.org/10.1016/S0165-0114(98)00122-5

Yu, V. F.; Hu, K. J. 2010. An integrated fuzzy multi-criteria approach for the performance evaluation of multiple manufacturing plants, Computers and Industrial Engineering 58(2): 269-277. http://dx.doi.org/10.1016/j.cie.2009.10.005

Zadeh, L. A. 1965. Fuzzy sets, Information and Control 8(1): 338-353. http://dx.doi.org/10.1016/S00199958(65)90241-X 
Zavadskas, E. K.; Antucheviciene, J. 2006. Development of an indicator model and ranking of sustainable revitalization alternatives of derelict property: a Lithuanian case study, Sustainable Development 14(5): 287-299. http://dx.doi.org/10.1002/sd.285

Zavadskas, E. K.; Antucheviciene, J. 2007. Multiple criteria evaluation of rural building's regeneration alternatives, Building and Environment 42(1): 436-451. http://dx.doi.org/10.1016/j.buildenv.2005.08.001

Zavadskas, E. K.; Kaklauskas, A.; Sarka, V. 1994. The new method of multicriteria complex proportional assessment of projects, Technological and Economic Development of Economy 1(3): 131-139.

Zavadskas, E. K.; Kaklauskas, A.; Turskis, Z.; Tamošaitienė, J. 2008a. Selection of the effective dwelling house walls by applying attributes values determined at intervals, Journal of Civil Engineering and Management 14(2): 85-93. http://dx.doi.org/10.3846/1392-3730.2008.14.3

Zavadskas, E. K.; Kaklauskas, A.; Vilutiene, T. 2009a. Multicriteria evaluation of apartments blocks maintenance contractors: Lithuanian case study, International Journal of Strategic Property Management 13(4): 319-338. http://dx.doi.org/10.3846/1648-715X.2009.13.319-338

Zavadskas, E. K.; Kaklauskas, A.; Turskis, Z.; Tamosaitiene, J. 2009b. Multi-attribute decision-making model by applying grey numbers, Informatica 20(2): 305-320.

Zavadskas, E. K.; Turskis, Z. 2010. A new additive ratio assessment (ARAS) method in multicriteria decision-making, Technological and Economic Development of Economy 16(2): 159-172. http://dx.doi.org/10.3846/tede.2010.10

Zavadskas, E. K.; Turskis, Z.; Tamošaitienè, J. 2010a. Risk assessment of construction projects, Journal of Civil Engineering and Management 16(1): 33-46. http://dx.doi.org/10.3846/jcem.2010.03

Zavadskas, E. K.; Turskis, Z.; Tamošaitienè, J.; Marina, V. 2008b. Multicriteria selection of project managers by applying grey criteria, Technological and Economic Development of Economy 14(4): 462-477. http://dx.doi.org/10.3846/1392-8619.2008.14.462-477

Zavadskas, E. K.; Turskis, Z.; Vilutiene, T. 2010c. Multiple criteria analysis of foundation instalment alternatives by applying Additive Ratio Assessment (ARAS) method, Archives of Civil and Mechanical Engineering 10(3): 123-141.

Zavadskas, E. K.; Vilutiene, T.; Turskis, Z.; Tamosaitiene, J. 2010b. Contractor selection for construction works by applying SAW-G and TOPSIS GREY techniques, Journal of Business Economics and Management 11(1): 34-55. http://dx.doi.org/10.3846/jbem.2010.03

Zhao, R.; Govind, R. 1991. Algebraic characteristics of extended fuzzy numbers, Information Science 54(1): 103-130. http://dx.doi.org/10.1016/0020-0255(91)90047-X

Zopounidis, C.; Doumpos, M. 2002. Multicriteria decision aid in financial decision making: methodologies and literature review, Journal of Multi-Criteria Decision Analysis 11: 167-186. http://dx.doi.org/10.1002/mcda.333

Alvydas BALEŽENTIS. Ph.D. (HP) in management and administration, is Professor at the Department of Strategic Management in Mykolas Romeris University. While working at the Parliament of the Republic of Lithuania, Ministry of Agriculture, and Institute of Agrarian Economics he contributed to creation and fostering of the Lithuanian rural development policy at various levels. His scientific interests cover areas of innovatics, strategic management, sustainable development, and rural development.

Tomas BALEŽENTIS is student of economics (economic analysis) at the Faculty of Economics in Vilnius University. His working experience includes traineeship at the European Parliament and working at the Training Centre of the Ministry of Finance. His scientific interests: quantitative methods in social sciences, multi-criteria decision making, European integration processes.

Algimantas MISIŪNAS. Ph.D. in social sciences, is Associate Professor at the Department of Quantitative Methods and Modelling in Vilnius University. His scientific interests cover areas of macroeconomic analysis, macroeconomic models, forecasting of economic processes, informal economy. 


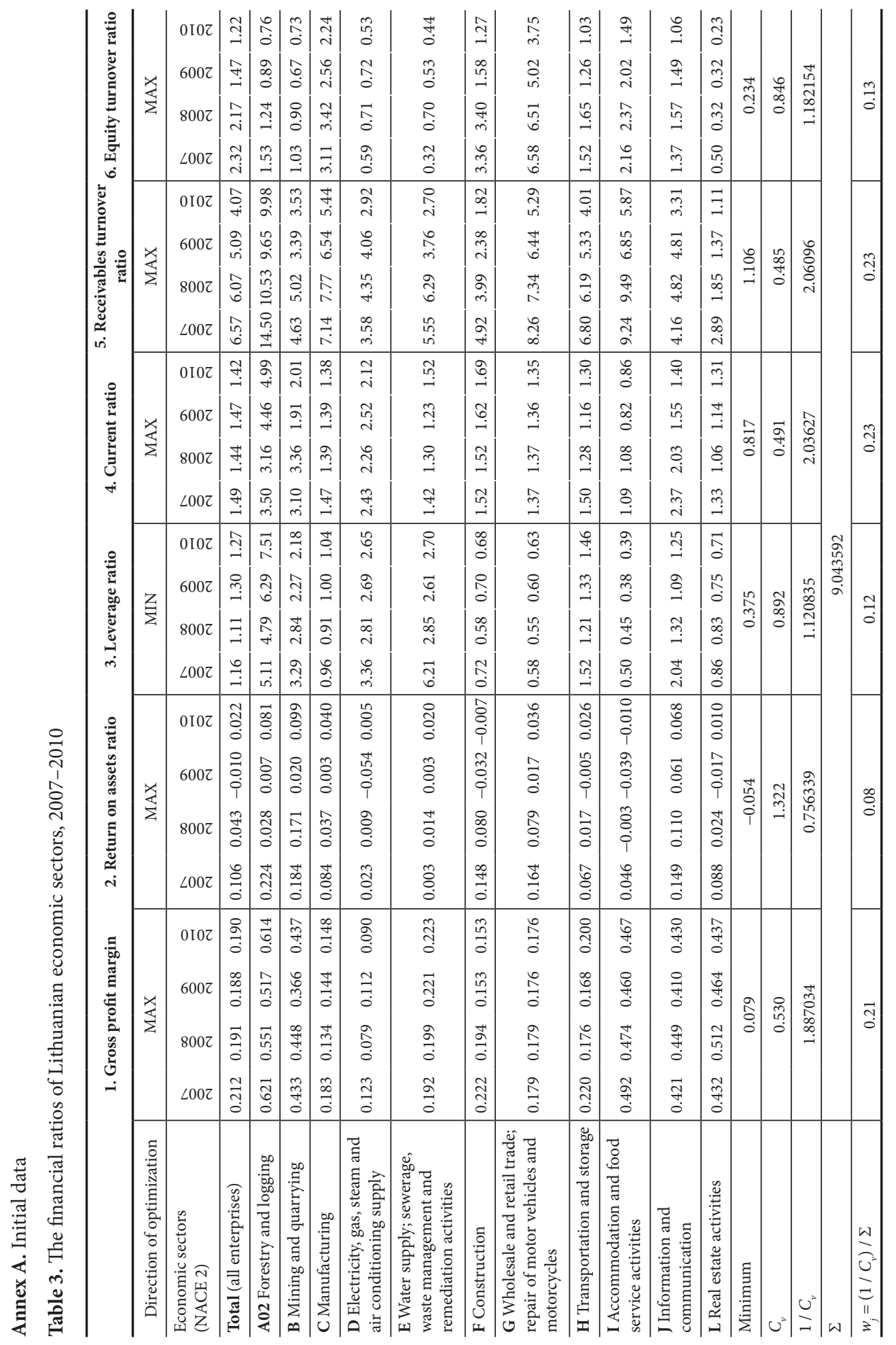




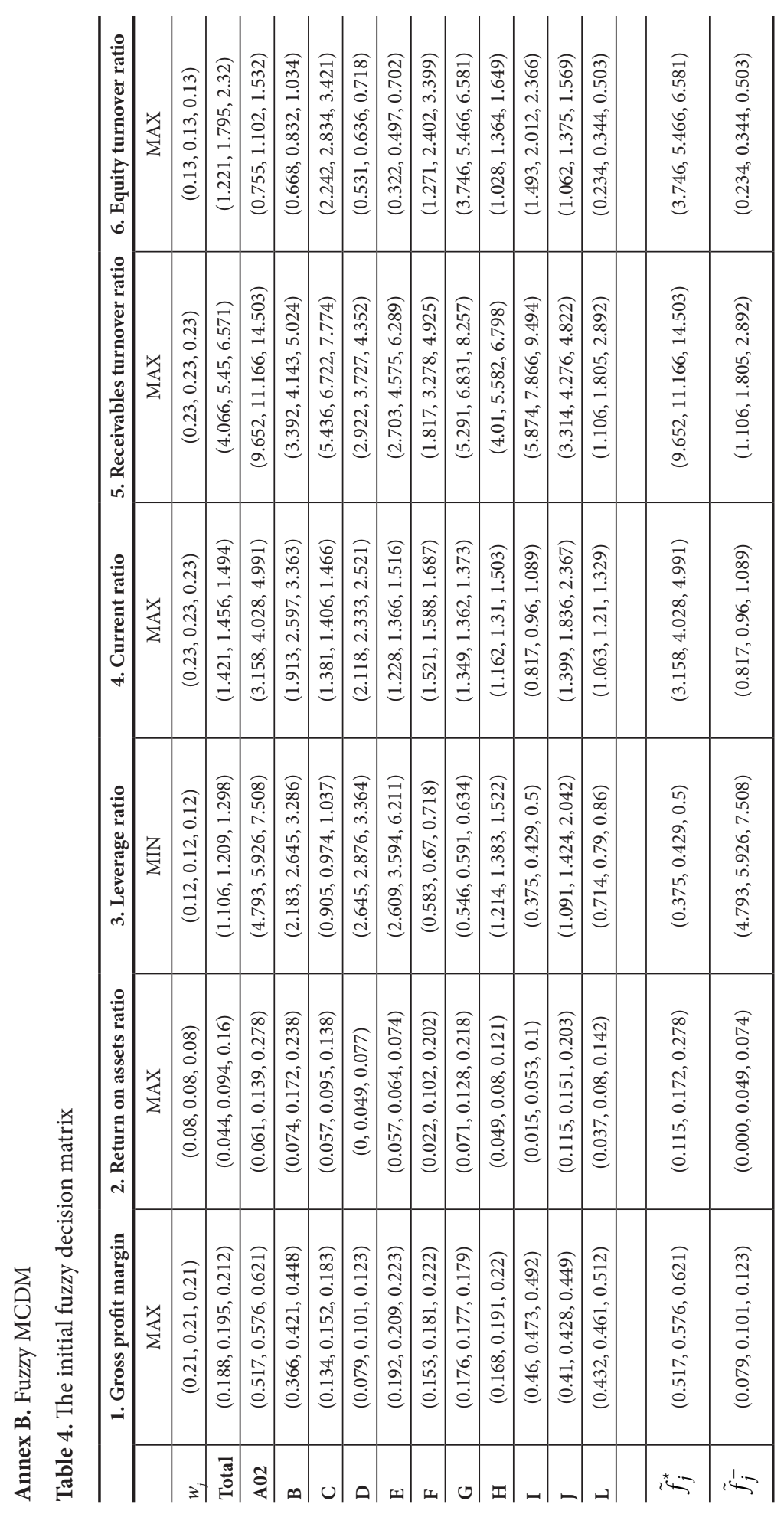

